\title{
自然換気併用外気制御システムをもつ空調室の熱負荷計算法に関する研究 \\ A STUDY ON A THERMAL LOAD SIMULATION METHOD FOR SPACES CONDITIONED BY HEATING, COOLING AND FRESH AIR CONTROL SYSTEMS COMBINED WITH NATURAL VENTILATION
}

\author{
郡 公子*，石野久彌**，村上周三*** \\ Kimiko KOHRI, Hisaya ISHINO and Shuzo MURAKAMI
}

\begin{abstract}
This paper proposes a thermal load simulation method for spaces conditioned by heating, cooling and fresh air control systems combined with natural ventilation. Fresh air control systems enables free cooling, demand control ventilation and energy recovery ventilation. Natural ventilation may be carried out while spaces are conditioned by cooling equipment. The assumptions in simulating natural ventilation and fresh air control and a solution method of multi-zone heat balance and fresh air rate are presented. The proposed simulation method was applied to the building simulation engine in BEST. The simulations of office buildings were performed and their results show the usefulness of the proposed method.
\end{abstract}

Keywords : Natural ventilation, Free cooling, Demand control ventilation, Heat recovery ventilation, Thermal load simulation 自然換気，外気冷房，最小外気量制御，全熱交換器，熱負荷計算

\section{1. はじめに}

外気冷房や $\mathrm{CO}_{2}$ 濃度による最小外気量制御、全熱交換器による熱 回收などの外気制御システムは、従来からよく採用される省エネ手 法である。他方で、オフィスの自然換気が一般化し、冷房中に自然 換気を行うハイブリッド空調も導入されるようになった。これらは、 種々の運転許可条件があり、室温制御機能をもつものもある。最大 熱負荷や年間熱負荷の計算において、ある程度現実的な運転を想定 して効果を予測できるようになると、ファサードの断熱性能の向上 に伴う冷房負荷増大に対寸る自然換気や外気冷房の効果、今後の内 部発熱減少傾向に伴う暖房負荷発生に対する外気負荷抑制策である 最小外気量制御や全熱交換器の効果を、容易に定量評価可能になる。

自然通風・機械換気を考慮する熱負荷計算法は、住宅用に研究が 進み 1)症ど、住宅に対しては、熱・換気平衡を解く計算法が一般化し ているものの、通風・換気の運転法は比較的シンプルであり、室温 制御機能は通常もたない。国内で広く利用されている熱負荷計算ツ ール New HASP/ACLD は、全熱交換器を併用する外調機の計算が 可能であるが、ごく単純な運転や仮定条件を想定し簡易化を図って いる 2)。エネルギー消費量を求めるためのシステムシミュレーショ ンを含む建築・設備統合計算法を利用寸ると、外気制御システムの 計算は可能である。国内ツールの HASP/ACSS ${ }^{3)}$ 、EESLISM ${ }^{4)}$ など は外気制御の計算が可能であり、BEST の連成計算 5 、海外の代表
的なツールである EnergyPlus ${ }^{6)}$ 、換気計算ツール COMIS の併用や ユーザのプログラム追加が可能な TRNSYS7)などは自然換気を併用 する計算も可能である。しかし、これらの計算法は、多様なシステ ムに適用可能とするため入力項目が多い、計算時間間隔を短くする 必要がある、収束計算やフィードバック制御の安定性に問題が生じ ることがあるなどの傾向があり手軽とは言えない。

本研究は、従来の熱負荷計算法に自然換気併用外気制御の計算機 能を追加し、手軽に利用可能と寸ることを目的としている。風量収 支は解かず、熱平衡計算の複雑化を抑える工夫を行った。提案した 計算法を BEST の非連成計算（熱負荷計算） 8 亿組み込み、数值計 算によりその有用性を確認した。

\section{2. 対象とする自然換気・外気制御の運転法と換気計算法}

外気制御システムは、熱負荷計算における空調装置の扱いと同様 にゾーンごとに設けられ、独立した制御を行うものとする。自然換 気も、換気口のあるゾーンごとに制御されるものとする。対象とす る自然換気・外気制御の運転法を表 1 にまとめた。自然換気は、事 例調査 9)をとに設定できる許可条件を決めた。下限室温に対して は、実際の運転では換気口を閉あるいは開操作するのが普通である が、計算時間間隔が 1 時間程度であることを考えて、開口率調整に よる下限室温制御に置き換えた。冷却中の自然換気に関しては、許

\footnotetext{
* 宇都宮大学地域デザイン科学部 教授・工博

** 首都大学東京 名誉教授. 工博

***＼cjkstart建築環境・省エネルギー機構＼cjkstart理事長·工博
}

Prof., Faculty of Regional Design, Utsunomiya Univ., Dr.Eng.

Emeritus Prof., Tokyo Metropolitan Univ., Dr.Eng.

President, Institute for Building Environment and Energy Conservation, Dr.Eng. 


\section{自然換気の許可条件}

(スケジュール・屋外条件)

1)自然換気許可時間带

3)外気相対湿度 $\leqq$ 上限值

5)屋外風速 $\leqq$ 上限值

(室内条件)

6)室温>外気温(必須)

8)室温 $\geqq$ 下限值

(空調装置条件)

9)加熱処理していない(必須)
2)外気温度 $\geq$ 下限值

4)外気露点温度 $\leqq$ 上限值

7)室内エンタルピ>外気エンタルピ

10)冷却処理していない

\section{自然換気の開口率調整（室温下限値制御）}

室温が下限值を下回らないよう、開口率調節を行う（開口率は、実際 の運転での換気口の開放時間率に相当する)。

\section{外気冷房の許可条件}

(スケジュール・屋外条件)

1)外気冷房許可期間の換気時間帯

2)外気温度 $\geqq$ 下限値

3)下限值 $\leqq$ 外気露点温度 $\leqq$ 上限値

(室内条件)

4)室温>外気温(必須)

6) 室温 $\geqq$ 下限值

(空調装置条件)

7)加熱処理していない(必須)
外気冷房の外気導入量調整（室温下限值制御）

室温が下限值を下回らないよう、導入量調節を行う。

外気冷房と自然換気の併用

自然換気を優先。室温下限值制御は、両者の設定值の高い值を採用。

\section{最小外気制御の許可条件}

（スケジュール・空調装置条件）

1)最小外気制御期間の換気時間带 2)外気冷房を行っていない(必須)

3)外気導入量 $\geqq 下$ 限值

\section{全熱交換器の運転許可条件}

(スケジュール)

1)全熱交運転許可期間の換気時間帯

(室内・空調装置条件)

2)冷却あるいは加熱中(必須)

3)室内エンタルピく外気エンタルピ（冷却中）

室内エンタルピ>外気エンタルピ (加熱中)

4) 室温<外気温（冷却中)

室温>外気温（加熱中、加熱不要とするための回収率調整あり)

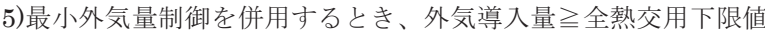

\section{全熱交換器の熱回収率調整}

内外温度差チェックを行うとき、可能な場合は加熱せずに室温を設定 值に保つように熱回収率の調整を行う。
可する場合としない場合を選択できる。外気冷房は、下限室温を冷 房設定室温より低く設定できるようにして、控えめの冷房に対して 外気冷房は積極的に行いより快適な室内環境をつくる運転を評価で きるようにした。自然換気と併用する場合は、下限室温を両者の高 い方の值で統一した上で、自然換気を優先し不足なら外気冷房も行 う。最小外気量制御は、下限外気量以上であれば、在室率に等しい 比率で外気量を絞るという簡単な計算とした。また、外気冷房中は 不許可と寸るが、それ以外はエネルギー上の有利不利とは無関係に 運転を許可するという通常の運用法に合わせた。全熱交換器は、空 調機で顕熱処理を行っているときの夕運転を許可する。省エネに配 慮して、内外ェンタルピや内外温度の関係をチェックすることが可 能で、内外温度チェックを行うときは全熱交換器の熱回収率調整に よる室温制御も行う。全熱交換器による室温制御には、発停、回転 数、バイパス風量の調整による方法が考えられるが、熱負荷計算上 の扱いは同じで、加熱せずに室温を設定值に保つことのできる熱回 収率を求める。最小外気量制御と全熱交換器を併用する場合は、極 端な少風量運転によるエネルギー的な逆効果を避けるために下限外 気量を設定できる。

自然換気計算は、非住宅を主な計算対象と考え、風量収支を解か ない簡単な方法を採用することにした。風量収支を解くためには建 物内全ての空間の熱・換気計算が必要となること、エントランスを 始め不明瞭な隙間や開口が多いことなどから、条件設定の手間に対 して十分な精度を得られるとは言えないと判断した。換気口の方位 角と有効開口面積を与えて、換気口ごとに独立して差圧・風量計算 をする。計算上の主な仮定は次のようになる。

1）建物内を 1 空間と扱い、無風時の中性帯高さを仮定する（建物 高さの $2 / 3$ の高さ)。

2)各ゾーンの中央高さ（天井高の $1 / 2 ）$ を差圧計算点とする。

3)差圧計算に用いる建物内空気温度は、換気口のあるゾーンの前 時間ステップの室温で代表させる。

4)風圧による室内圧変動は、換気口面と $180^{\circ}$ 反対側の屋外面の
風圧の平均とする。

本計算法は、自然換気の経路計画や換気口設計には適さないが、 種々の自然換気許可条件を考慮できるので自然換気の運用法の検討 や省エネ効果の評価には適している。計算法の妥当性を確認するた めに、実測值との傾向比較を行っている 10),11)。自然換気ビルの実測 研究論文の中から計算に必要な最低限の条件が揃っているものを選 び、計画段階での予測を想定して標準年気象データを用いる計算を 行い、室温、換気時間や換気量の予測值を求め、実測值と比較する という方法である。傾向を概ね予測できたケースと予測できたとは 言えないケースがあるが注 1)、感度解析を組み合わせることで計画段 階での利用は可能と判断できる。今後、換気の数值解析を別途進め 12)、外皮・内皮の漏気性やボイド配置、風圧による建物内差圧特性 の傾向を把握し、建物全体を代表するゾーンの設定法や誤差の検討 を行う予定である。

\section{3. 自然換気併用外気制御システムをもつ空調室の熱平衡計算法}

多数ゾーンの非定常熱平衡計算は、一般によく利用される陰解法

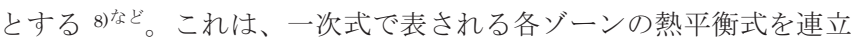
させて解くもので、未知数は現在の室内温湿度あるいは空調供給熱 量である。熱平衡式の未知数や定数が、正常な冷暖房、冷暖房不要、 冷暖房能力不足などの運転状態により恋わる不連続現象であるた め、熱平衡計算を何回か反復し該当する運転状態を探索して解を求 める。

自然換気や外気制御システムを計算対象に加えると、外気量も未 知数となる。具体的には、最小外気量、設計外気量、最大外気量、 外気量調整などの外気導入状態の探索も必要となり、計算手順が煩 雑となる。隣接ゾーンの影響を受けるため、探索過程で振動が生じ、 反復回数が増大寸る恐れも考えられる。

そこで、反復計算中の外気量の頻繁な仮定值変更を抑制するため に、装置容量の割増や仮想ヒータの想定などの置換を導入し、外気 量が不正解でも室温は正解を得やすくする方法を考案した。室温が 


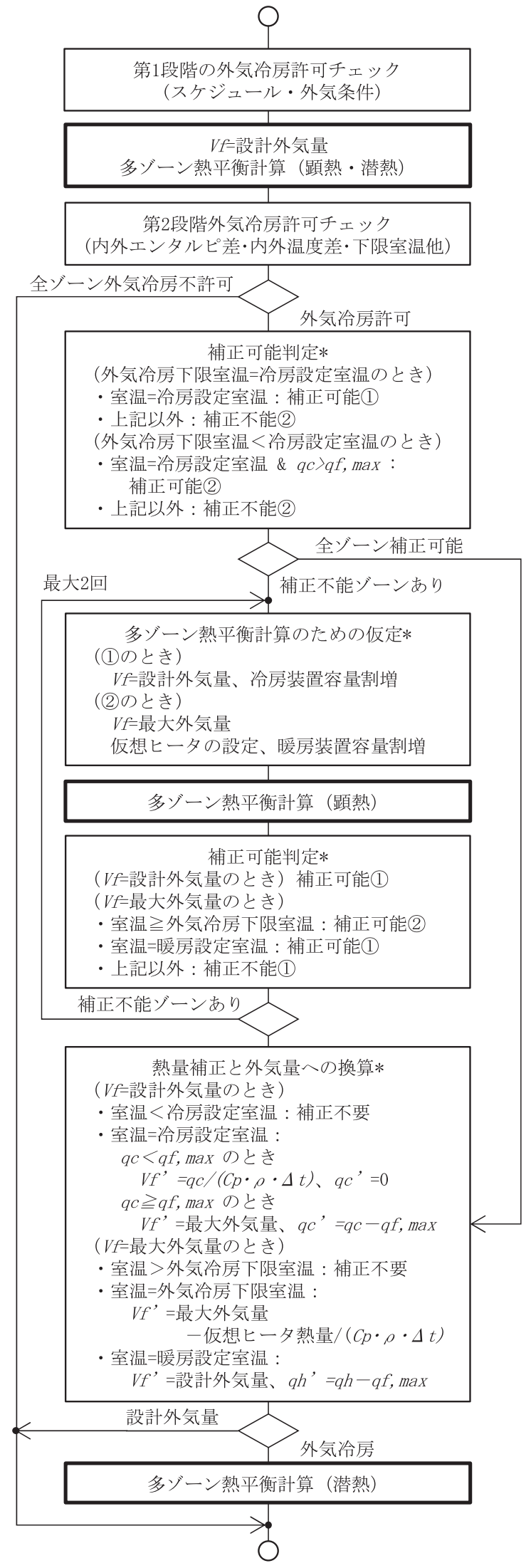

1) 記号は次の通り。 $V f 、 q c 、 q h$ : 外気量、冷却熱量、加熱量 (夕゙ ッシュ付きは補正後の值）、 $q f, \max$ : 外気冷房最大冷却熱量、 $\Delta t$ : 内外温度差、 $C p, \rho$ : 空気の比熱、密度（熱量、 $\Delta t$ は正） 2) 多ゾーン熱平衡状態は、何回か連立方程式を解いて求める。 3)*付きの処理は、外気冷房が許可されたゾーンに対して行う。 4) 1)、(2)は、再計算するときに仮定する外気量タイプ

図 1 外気冷房の場合の熱平衡計算フロー
正解であれば、得られた熱量を補正・換算して正解の熱量や外気量 を求めることが可能である。これにより外気導入状態の探索中の振 動はほぼ抑えられ、熱平衡計算の反復回数を減らしてスムーズに解 が得られるようになる。

外気冷房の場合を例に、計算法を述べる。図 1 に、熱平衡計算の フローを示す。第 1 段階の外気冷房許可チェックを行った後、まず 設計外気量を仮定して多数ゾーンの顕熱潜熱平衡計算を行う。得ら れた室内状態をもとに第 2 段階の外気冷房許可チェックを行う。熱 的相互影響のある全てのゾーンに対して外気冷房不許可であれば熱 平衡計算は終了寸る。さらに、熱量補正で解が得られるかを判定し、 補正不能ゾーンが 1 ゾーンでもあれば、外気量を仮定し直して熱平 衡の反復計算を開始する。第 2 段階で外気冷房が許可されても、隣 接ゾーンの外気冷房の影響が強いときには、最終的に外気冷房下限 室温未満や暖房要求となり外気冷房不許可に変わる場合もある。

反復計算中の外気量の仮定值は、設計外気量か最大外気量かのい ずれかとし、外気量仮定值に応じて表 2 に示寸置換を行う。設計外 気量を仮定する場合には、外気冷房が加わる効果を冷房装置容量の 割増しに置き換える。最大外気量を仮定する場合には、外気量調整 による下限室温制御を仮想ヒータによる制御に置き換えると同時 に、暖房装置容量を割増すことで過剩外気導入の仮定による能力不 足を防ぐ。このような条件設定のもとで多数ゾーンの顕熱平衡計算 を行い、その結果からさらに反復が必要か判定する。補正不能ゾー ンがあれば計算条件の再設定、再計算を行う。顕熱平衡計算の反復 は、最大 3 回で十分と考えて 3 回で打ち切る。

全てのゾーンが補正可能、即ち室温の正解が得られると、ケース に応じて熱量補正や外気量への換算を行う。外気冷房を行う場合の み、潜熱平衡を再計算する。

自然換気やその他の外気導入制御を含めると、計算手順はやや複 雑になるが、基本的な考え方は同じである。自然換気と外気冷房が ともに許可された場合は、外気冷房の最大外気量に自然換気最大量 を含めて計算処理する。全熱交換器を用いる場合は、効率の効果を 見込んだ等価外気量 $(=(1$ - 全熱交換器熱回收率 $) \times$ 外気量 $)$ を用いる。

\section{4. 自然換気併用外気制御システムをもつオフィスの基本特性}

本研究で提案した自然換気および外気制御システムの計算法を BEST の熱負荷計算に組み込んだ。東京の南向き中間階に位置し、 ペリメータ、インテリアの 2 ゾーンを有するオフィス断面を想定し

\section{表 2 顕熱平衡計算における外気冷房の置換手法と結果補正手法}

\begin{tabular}{|c|c|c|}
\hline 置換 & 置換の意味と具体的な条件 & $\begin{array}{c}\text { 熱平衡状態 } \\
\text { 確定後の補正 }\end{array}$ \\
\hline $\begin{array}{l}\text { 冷房装置容 } \\
\text { 量の割増 }\end{array}$ & $\begin{array}{l}\text { 設計外気量を仮定する計算用。最大外 } \\
\text { 気冷房能力(設計外気量に対し最大外 } \\
\text { 気量に増やした場合の外気の冷却熱増 } \\
\text { 分)を冷房装置容量に追加する。 }\end{array}$ & $\begin{array}{l}\text { 冷却量の割 } \\
\text { 引、外気導入 } \\
\text { 量の換算 }\end{array}$ \\
\hline $\begin{array}{l}\text { 下限室温調 } \\
\text { 整用ヒータ } \\
\text { の想定 }\end{array}$ & $\begin{array}{l}\text { 最大外気量を仮定する計算用。下限室 } \\
\text { 温に保つぬ外気導入量の調整を仮 } \\
\text { 想ヒータの加熱に置換する。最大外気 } \\
\text { 冷房能力を相殺する加熱容量を仮定す } \\
\text { る。通常暖房時には停止。 } \\
\end{array}$ & $\begin{array}{l}\text { 仮想ヒータの } \\
\text { 加熱量から外 } \\
\text { 気導入量への } \\
\text { 換算 }\end{array}$ \\
\hline $\begin{array}{l}\text { 暖房装置容 } \\
\text { 量の割増 }\end{array}$ & $\begin{array}{l}\text { 最大外気量を仮定する計算用。最大外 } \\
\text { 気冷房能力を相殺する加熱量を暖房装 } \\
\text { 置容量に追加する。 }\end{array}$ & $\begin{array}{l}\text { 加熱量の割 } \\
\text { 引、外気導入 } \\
\text { 量への換算 }\end{array}$ \\
\hline
\end{tabular}

自然換気、最小外気量制御、全熱交換器の場合も、上表と同様に 扱う。全熱交換器の効果は、等価外気量に置換する。 
表 3 主な計算条件と計算ケース（オフィス）

気象

$\mathrm{EA}$ 標準年気象デー夕（東京）

\section{外気制御}

(外気冷房)

下限外気温： $8^{\circ} \mathrm{C}$ 、内外ェ外比チェッあり

外気露点温度：上限 $19^{\circ} \mathrm{C}$ 、下限 $0^{\circ} \mathrm{C}$

下限室温：夏期 - 中間期 $24^{\circ} \mathrm{C}$ 、冬期 $26^{\circ} \mathrm{C}$

最大外気量:設計外気量の 3 倍

(最小外気制御)

下限外気量比(設計外気量に対する比)：0.25

(全熱交換器)

内外エン㸝 ・ 内外温度チェックあり

効率 : 全熱 $60 \%$ 、下限外気量比 : 0.5

\section{自然換気}

（自然換気制御）

自然換気期間 - 時間：4-11月 - 24 時間

下限外気温: $15^{\circ} \mathrm{C}$ 、上限外気相対湿度 : $90 \%$

上限外気露点温度 : 空調時 $19^{\circ} \mathrm{C}$ 、

上限屋外風速 : $10 \mathrm{~m} / \mathrm{sec}$

内外エン朼゚チェッあり、冷房中も許可

下限室温：空調時 $24^{\circ} \mathrm{C}$. 非空調時 $22^{\circ} \mathrm{C}$

(建物) 8 階建て (軒高 $32 \mathrm{~m}$ )、対象室 2 階
（換気口）単位外皮長さあたり有効開口面積 $0.005 \mathrm{~m}^{2} / \mathrm{m}$

\section{対象室}

（室）中間階ペリメータ・价师ア 2 ゾーン断面

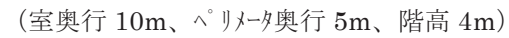

南向き、ゾーン間換気量 $250 \mathrm{CMH} / \mathrm{m}$

(空) Low-E 複層氒ラス・内側明色ブライド、

空面積率 $70 \%$

(内部発熱(最大)) 照明 $10 \mathrm{~W} / \mathrm{m}^{2}$ 、機器 $15 \mathrm{~W} / \mathrm{m}^{2}$ 、 在室者 0.15 人 $/ \mathrm{m}^{2}$

\section{空調}

(空調時間) 8：00-22:00(室使用 9:00-22:00)

（設定室温・湿度）夏期(6-9 月） $26^{\circ} \mathrm{C} 60 \%$ 中間期 $(4 \cdot 5 \cdot 10 \cdot 11$ 月)及び冬期 $(12-3$ 月)

冷房 $26^{\circ} \mathrm{C}$ 、暖房 $22^{\circ} \mathrm{C} 40 \%$

(設計外気量) $3.75 \mathrm{CMH} / \mathrm{m}^{2}$

計算ケース

採用手法なし：外気制御・自然換ともになし

外気冷房 : 外気冷房のみあり

十自然換気：外気冷房・自然換気

十最小外気制御：上記条件に最小外気制御追加 +全熱交換器(全手法)：上記条件に全熱交追加
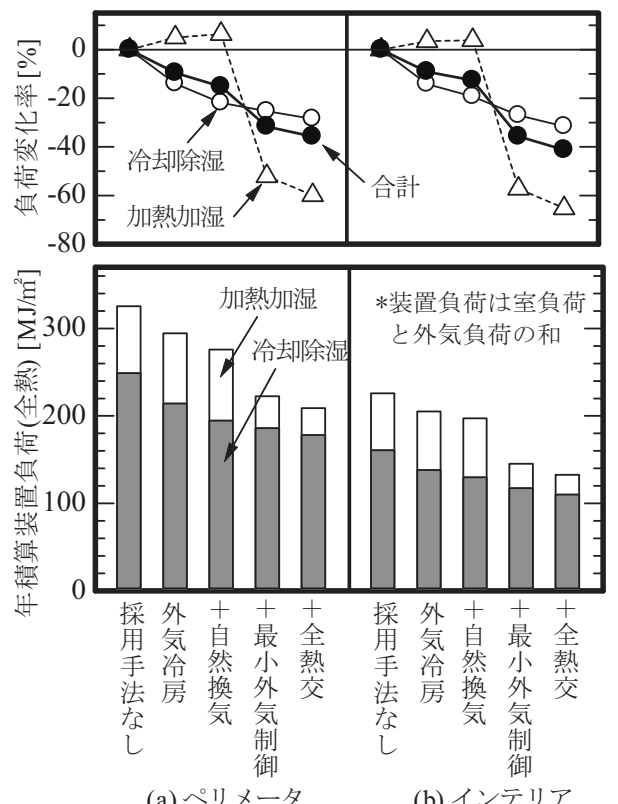

(a)ペリメータ

(b) インテリア

図 2 各ケースの年積算装置負荷
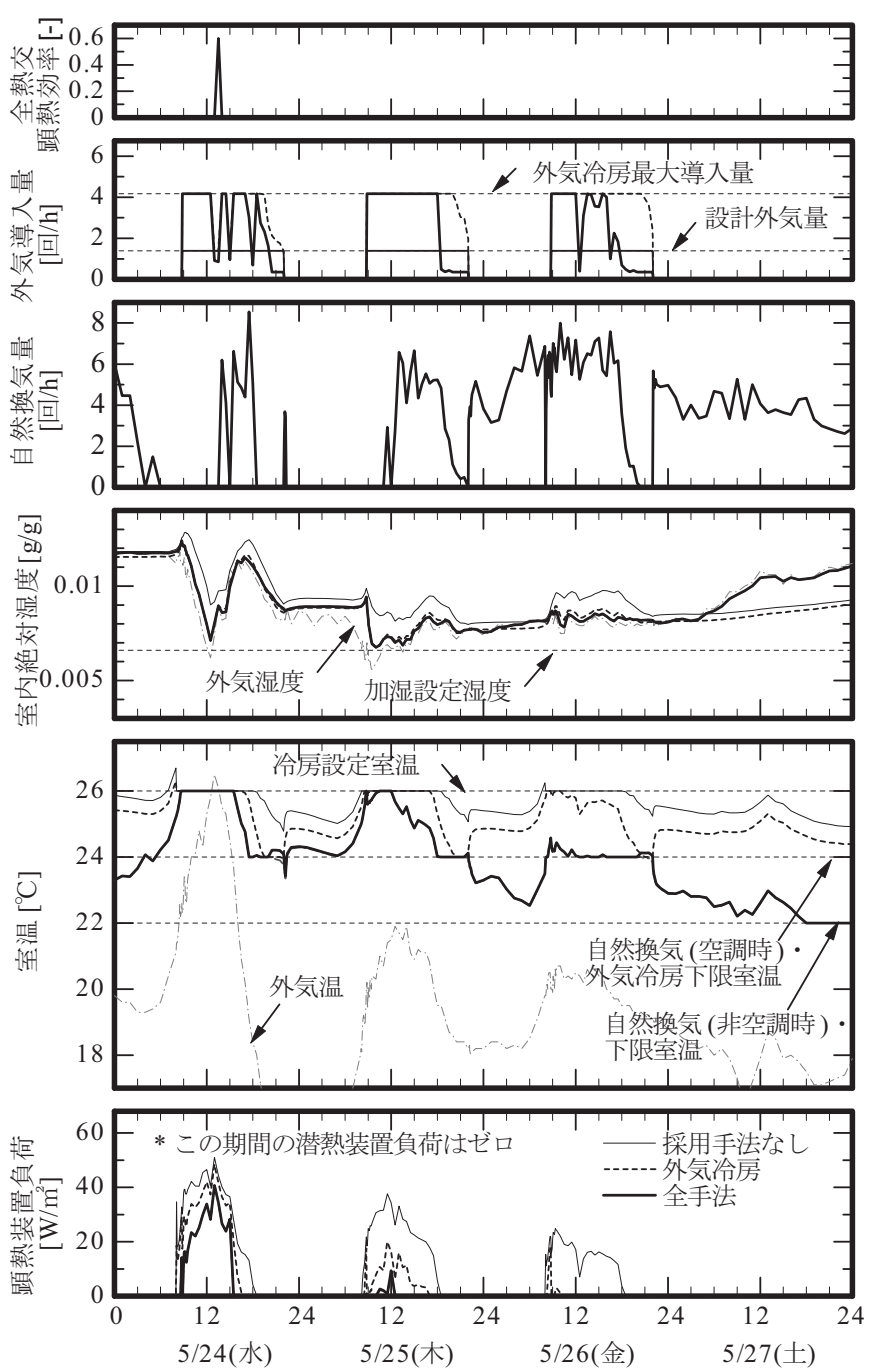

図 3 中間期の室内環境 - 負荷と外気制御状態 (ペリメータ)
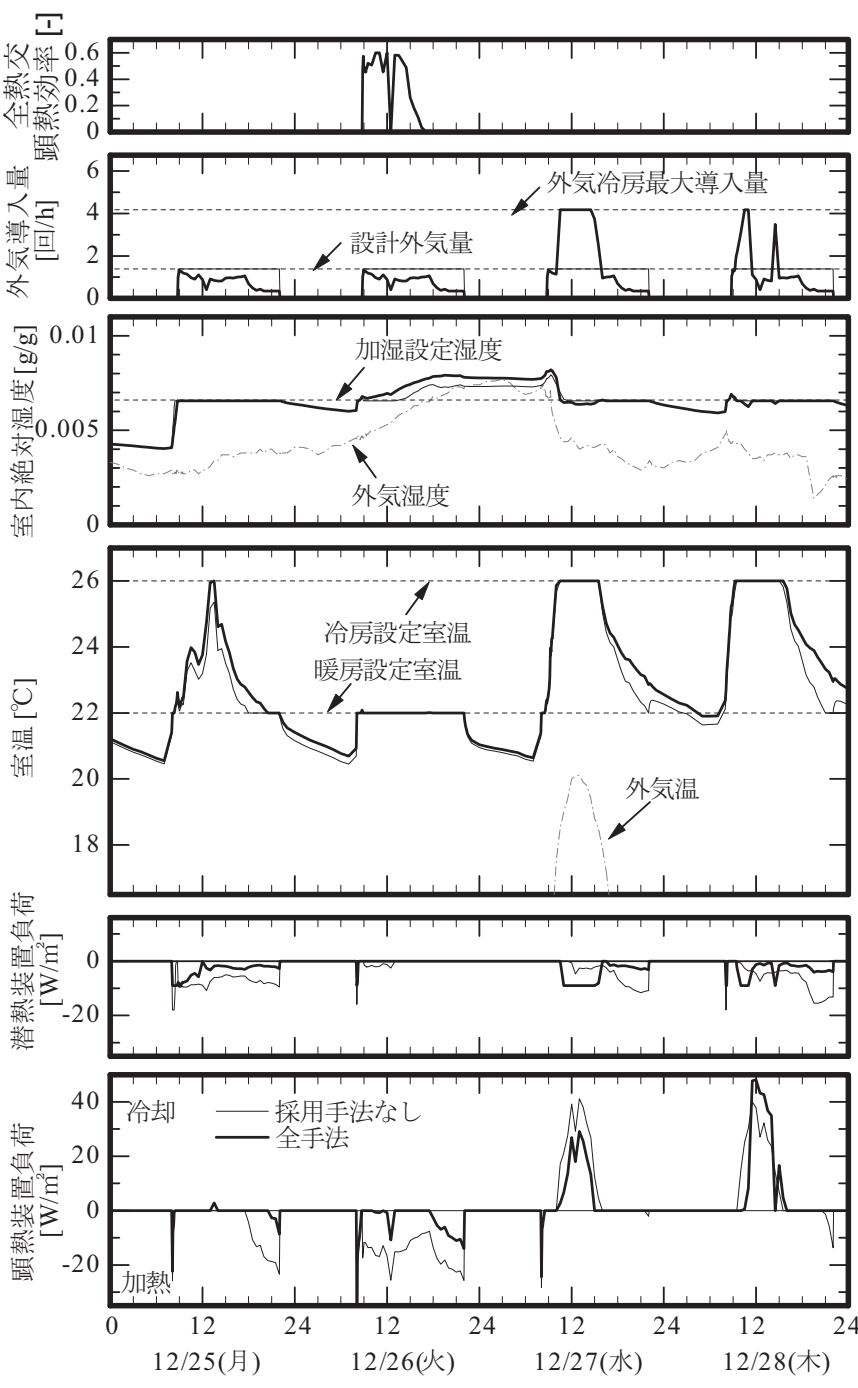

図 4 冬期の室内環境 - 負荷と外気制御状態 (ペリメータ) 
表 4 低性能・高性能建築の条件（表 3 に対する変更点）

\begin{tabular}{l|l|l}
\hline \multicolumn{1}{c|}{ 手法 } & 低性能建築 & 高性能建築 \\
\hline ファサード & 単板ガラス空 & ダブルスキン \\
\hline 自然換気・外気冷房・ & なし & あり \\
最小外気量制御・全熱交 & な & \\
\hline
\end{tabular}

【表 4 ・図 5 注記】1) 単板ガラス空は熱反ガラスの一般空、ダ ブルスキンは外側透明単板・内側 Low-E 複層ガラス (内空面 積率 68\%)で、ダブルスキン内自然換気制御あり 2) 年積算 装置負荷 (冷却除湿/加熱加湿) $\left[\mathrm{MJ} / \mathrm{m}^{2}\right]$ は、低性能建築のペリ メータ 281/141、インテリア 152/86、高性能建築のペリメー タ 173/18、インテリア $119 / 16$

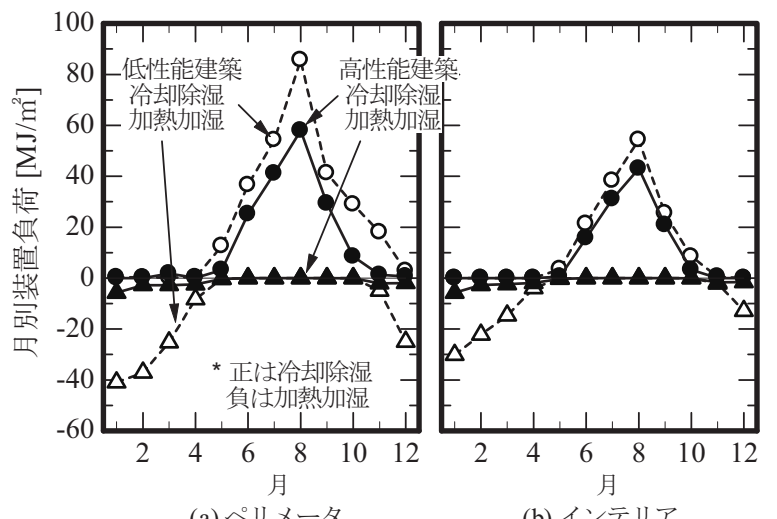

(a)ペリメータ

(b) インテリア
【図 6 注記】「ファサード」は、一般空からダブルスキンに変更することによる高 性能化手法のこと。「十」でつないだ手法は 2 手法併用のこと
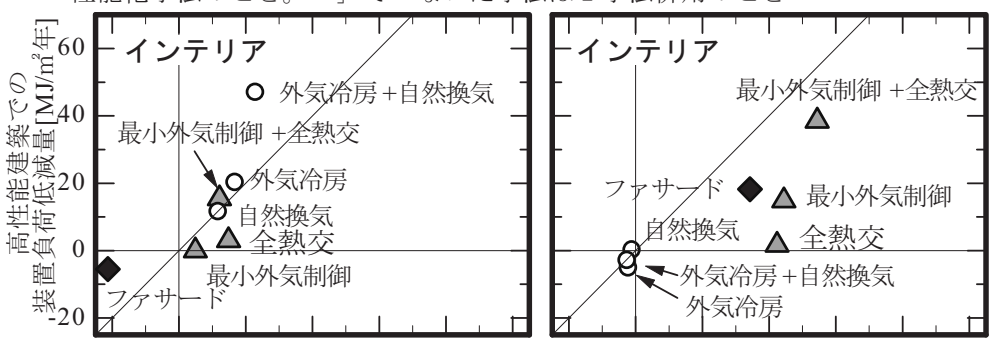

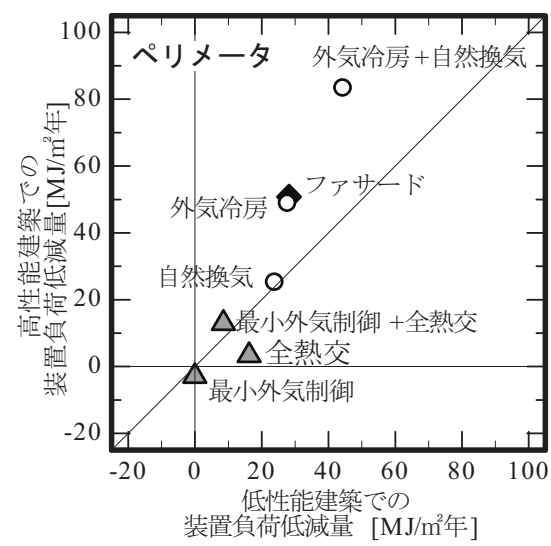

置負荷低減量 $\left[\mathrm{MJ} / \mathrm{m}^{2}\right.$ 年 $]$

(a) 冷却除湿負荷

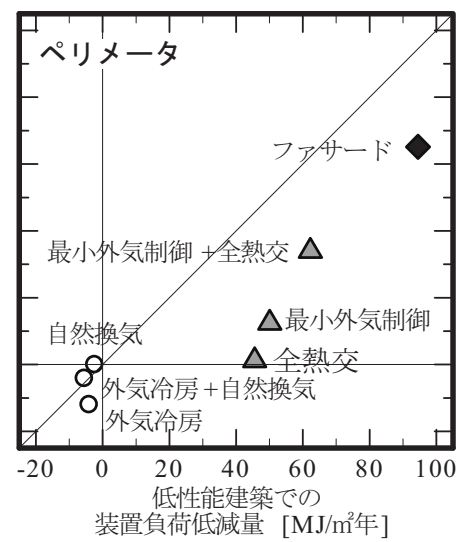

(b) 加熱加湿負荷
図 6 低性能、高性能建築に対する各手法の負荷低減効果の相関

\section{5. 低性能・高性能建築に対する省エネ手法の効果}

本研究で提案する熱負荷計算法により、建築的な省エネ手法と自 然換気や外気制御との組合せ効果を評価できるようになった。そこ で、表 4 に示寸低性能建築と高性能建築を想定して、ファサードの 高性能化手法と自然換気、外気制御の各手法の省エネ効果を比較し た。一般に、省エネ手法の評価は、低性能建築に対する省エネ手法 の付加による効果で評価されてきた。しかし、省エネ化が進んでい る現在、高性能建築に対する省エネ手法の評価が重要になりつつあ る。ここでは、高性能建築から対象とする省エネ手法を除いたこと による負荷変化量を、その手法の高性能建築に対する省エネ効果と 見な寸考え方をとる。この考え方では、手法を取り除いた後のケー スの条件は統一されていないので、手法を取り除く前の高性能建築 が省エネ効果の基準となる。低性能建築に対する省エネ効果は従来 通りの考え方である。

まず、低性能、高性能建築の負荷特性を確認した。図 5 に月別装 置負荷を示す。冬期の泠房設定室温を $26^{\circ} \mathrm{C}$ と高めにしていることか ら、高性能建築、低性能建築ともに冬の冷却除湿負荷はほとんどな い。また、高性能建築は、低性能建築に対して、加熱加湿負荷がゼ ロに近い、両建築の夏期、中間期の冷却除湿負荷の差は、ペリメー タゾーンでは大きいが、インテリアゾーンではそれほど大きくない。

図 6 に、低性能、高性能建築に対寸る各手法の負荷低減量の相関 を示した。外気冷房や自然換気は、高性能建築の冷房負荷増大を相 殺できるので、低性能建築と同等以上の冷却除湿負荷低減を期待で きる。特に外気冷房は、自然換気より低温外気域でも利用が可能で あり、中間期・冬期に生じる最小外気量制御の逆効果も抑制できる ので、高性能建築に有利となる。最小外気量制御や全熱交換器は、 暖房負荷が大きくなりがちな低性能建築で効果が大きい。全熱交換 器と最小外気量制御の併用は、どちらか単独で利用寸る場合に対し 
てそれほど負荷低減量が増えないことに留意が必要である。ファサ ードの高性能化は、低性能建築、高性能建築の両方のペリメータゾ ーンに対して大きな加熱加湿負荷低減の効果があり、さらに冷却除 湿負荷の低減は、低性能建築より高性能建築に顕著であるという結 果が示された。インテリアゾーンに現れるファサードの高断熱化に よる冷却除湿負荷増大も高性能建築の方が低性能建築より小さく、 ファサード高性能化に伴うデメリットを相殺する能力を持つ高性能 建築の特徵が現れている。

\section{6. まとめ}

本研究は、自然換気併用外気制御システムをもつ空調室の熱負荷 計算法を提案することにより、建築的な省エネ手法と外気に関する 省エネ手法との組合せ効果を容易に定量評価できるようにしたもの である。その成果は、以下のようにまとめられる。

1)自然換気や外気制御システムの計算法を示した。自然換気は、風 量収支を解かず中性帯位置を仮定する簡易な計算法とするが、 種々の運転許可条件を考慮できるものとし、下限室温に対する換 気口の開閉動作は開口率調整による下限室温制御と扱い、 1 時間 間隔の計算に適するようにした。最小外気量制御は在室率を用い る簡易な計算法とした。外気冷房による下限室温制御、全熱交換 器の熱回収効率調整による室温制御の計算も可能とした。

2）自然換気併用外気制御システムに適する熱平衡計算法を提案し た。仮定した外気量に応じた装置容量の割増し、下限室温制御の ための外気量調整の仮想ヒータへの置換を行った上で顕熱平衡計 算を行い、得られた結果の補正・換算により正解を得る方法で、 計算手順の煩雑化を防ぎ、反復計算の回数を減らすことができる。

3）提案した計算法をBEST に組み込み、自然換気併用外気制御シス テムをもつ東京のオフィスの熱負荷計算を行った。自然換気併用 外気制御システムの省エネ効果が高いこと、自然換気や外気冷房 の積極利用により室内環境の改善が可能であることが示された。 冬期の外気冷房による加湿負荷増大、最小外気制御時に発生し得 る逆効果などの基本的な特性も確認できた。

4）建築的手法や自然換気・外気制御の複合効果を評価できることの 有用性を確認するため、低性能建築と高性能建築に対する各手法 の省エネ効果を評価した。低性能建築に対する省エネ効果は対象 手法の付加、高性能建築に対する省エネ効果は対象手法の削除に よる負荷変化量と考え、その相関特性を調べた結果、最小外気量 制御や全熱交換器は高性能建築より低性能建築で効果が高い、外 気冷房や自然換気併用外気冷房、ファサードの高性能化による冷 却除湿負荷低減は、低性能建築より高性能建築、特にペリメータ

$$
\text { ゾーンに対して効果が高いなどの特徵を把握できた。 }
$$

\section{謝辞}

本研究の一部は科研費補助金 $15 \mathrm{~K} 06320$ による。また、(一財)建 築環境・省エネルギー機構 BEST 専門版開発委員会統合化 WG およ び建築 SWGの委員各位に謝意を表する。

\section{参考文献}

1）石田建一、宇田川光弘：換気および壁面相互ふく射を考慮した多数室室 温・熱負荷計算法、日本建築学会計画系論文報告集、No. 381、pp. 46-55、 1987. 11

2）建築設備技術者協会：New HASP/ACLD 操作マニュアル、2012.12

3）日本建築設備技術者協会 : 空調システム標準シミュレーションプログラム HASP/ACSS/8502 プログラム解説書、1986

4）宇田川光弘、佐藤誠：EESLISM の特徴と利用法、空気調和・衛生工学会シ ンポジウム、熱負荷・空調ソフトウェアの現状と将来、pp. 55-68、2004. 3

5） IBEC : BEST-P D. 空調制御モジュールマニュアル、2013.7

6) The US Department of Energy: Engineering Reference The Reference to EnergyPlus Calculations, 2015

7) Solar Energy Laboratory: TRNSYS 17 Volume 4 Mathematical Reference, 2009

8）郡公子、石野久彌、長井達夫、村上周三 : 建築総合エネルギーシミュレー ションツールBEST のための建築シミュレーション法に関する研究、空気調 和・衛生工学会論文集、No. 162、pp. 9-15、2010.9

9）岩本博未、郡公子、石野久彌 : シミュレーションツール BEST によるオフ イスの熱負荷・熱環境解析 第 21 報 非住宅建築の自然換気動向調査、日 本建築学会大会学術講演梗概集 D-2、pp. 977-978、2015.9

10)岩本博未、郡公子、石野久彌：シミュレーションツール BEST によるオフ イスの熱負荷・熱環境解析 第 25 報 自然換気ビルの事例と数值解析によ る評価、日本建築学会大会学術講演梗概集 D-2、pp. 1037-1038、2016.8

11）郡公子、石野久彌、岩本博未：BEST による自然換気ビルの性能予測に関 する研究、空気調和・衛生工学会学術講演論文集、pp. 101-104、2015.9

12)下ノ園慧、郡公子、石野久爾 : シミュレーションツール BEST によるオフ イスの熱負荷・熱環境解析 第 26 報 建物開口配置と自然換気効果に関す る風量収支解析、日本建築学会大会学術講演梗概集 D-2、pp. 1039-1040、 2016. 8

13）郡公子、石野久彌、村上周三 : 外皮・躯体と設備・機器の総合エネルギ ーシミュレーションツール「BEST」の開発（その132）自然換気制御の計算 法、（その 158) 解法に応じた自然換気制御の想定法、(その 173) 自然換気併 用外気制御システムをもつゾーンの熱平衡計算、空気調和・衛生工学会学 術講演論文集、pp. 9-12、2014. 9、pp. 21-24、2015.9、2016

注

注 1) 自然換気ビル 3 件について実測值との傾向比較を行った。気象条件の似 ている 5 日間を比較した S ビルの場合 ${ }^{10)}$ 、換気回数の実測值 $0.8 \sim 1.2$ 回/ $\mathrm{h}$ に対して計算值 $0.8 \sim 1.8$ 回/h であった。また、中性帯に 1 層分近 づく、有効開口面積を 8 割にするという条件変更で、ともに換気回数は 0.2 回/ $\mathrm{h}$ 程度変化した。 $\mathrm{K}$ ビルの場合 ${ }^{10)}$ 、 ${ }^{11)}$ は、代表日の自然換気量の傾 向は概ね予測できたが、月別の換気時間や換気回数は、予測值と計算值 で傾向に違いがあった。 $K$ 大学の場合 ${ }^{11)}$ 、代表日の平均的な自然換気量、 月別換気時間の傾向は概ね予測できた。 


\title{
A STUDY ON A THERMAL LOAD SIMULATION METHOD FOR SPACES \\ CONDITIONED BY HEATING, COOLING AND FRESH AIR CONTROL SYSTEMS COMBINED WITH NATURAL VENTILATION
}

\author{
Kimiko KOHRI*, Hisaya ISHINO** and Shuzo MURAKAMI*** \\ * Prof., Faculty of Regional Design, Utsunomiya Univ., Dr.Eng. \\ ** Emeritus Prof., Tokyo Metropolitan Univ., Dr.Eng. \\ *** President, Institute for Building Environment and Energy Conservation, Dr.Eng.
}

This paper presents a thermal load simulation method for spaces conditioned by heating, cooling and fresh air control systems combined with natural ventilation. Fresh air control systems enables free cooling, demand control ventilation and energy recovery ventilation. Natural ventilation may be carried out while spaces are conditioned by cooling equipment.

For simulation of natural ventilation, many conditions which must be satisfied for natural ventilation can be considered and the under limit of space air temperature is supposed to be controlled by regulating ventilation opening area. On the other hand, natural ventilation rate is calculated under the simple conditions where airflow balance is not solved and the location of the neutral zone is assumed to be fixed. Space air temperature control by free cooling and heat recovery ventilation can be simulated. In demand control ventilation, ventilation rate is estimated in proportion of occupancy rate

For heat balance simulation of multi zones where fresh air control systems combined with natural ventilation are used, a new method was developed in order to enable speedy simulation and to avoid complicated procedure. In the proposed method for iterative solution of heat balance and fresh air rate which means sum of natural ventilation rate and forced ventilation rate for free cooling, space air temperature control by regulating fresh air rate is replaced for control by a virtual heater and cooling and heating capacities are intentionally increased. This procedure suppresses iteration of calculating fresh air rate and the solution such as heating rate, cooling rate and fresh air rate can be obtained by correcting the calculated results.

The proposed simulation method was applied to the building simulation engine in BEST which is a whole building energy and thermal load simulation program and the simulations for a typical office building located in Tokyo were performed. The basic effects of fresh air control techniques and natural ventilation on space thermal environment and thermal load were presented.

The interaction effects of energy saving strategies such as high performance building facades, natural ventilation and fresh air control techniques were evaluated through simulations in two buildings. One is a low-performance building and the other is a high-performance building. The energy saving rate for a low-performance building is defined as the thermal load reduction achieved by adding an energy saving strategy, and that for a high-performance building is defined as the thermal load increase resulted by removing the strategy employed in the high-performance building. Although some strategies provide lower energy savings for the high-performance building than for the low-performance building, a few strategies are more effective for the high-performance building. 